\title{
Gothic Heritage in Renaissance Mantua
}

\author{
Giulio Girondi \\ “Il Rio-Edizioni”, Mantua, Italy
}

\begin{abstract}
The aim of this paper is to present the less known phenomenon of late-Gothic Mantuan architecture in the second half of the 15th century. Indeed Mantua is famous for its Renaissance monuments. However, some of the Gonzaga palaces show Gothic details, such as towers or battlements. In addition, some patricians, merchants, and priests continued to follow the Gothic tradition until the final decade of the "Quattrocento". This paper will present a first list of these interesting architectures—both public and private, religious and profane — which, in some cases and despite the Gothic language, the archival research has demonstrated a late 15th century executions.
\end{abstract}

Keywords: Gothic heritage, Renaissance, Mantua, Gonzaga

\section{Introduction}

Mantua is well-known for its Renaissance monuments, built under the supervision of the Gonzaga family from the middle of the 15th century. Indeed, Ludovico II Gonzaga wanted that leading artists and architects—such as Andrea Mantegna and Leon Battista Alberti-join his court to transform the capital of the small marquisate into an international art center. On the other hand, if several patricians started to imitate the new "all'antica" style promoted by the Gonzaga court, others-such as noblemen, merchants and priests - continued to follow the Gothic tradition until the last decade of the "Quattrocento". For example, the church dedicated to the "Madonna della Vittoria" (1496) seems very important: Beyond its Gothic façades, this church originally housed the well-known altarpiece by Mantegna (now at Louvre) and important Renaissance frescoes_-just rediscovered by recent restorations_-almost certainly noted by Vasari (1568) who suggested that also the interior architecture of the small church was designed by Mantegna. This is not the only example of Gothic heritage in Renaissance Mantua: The church of San Cristoforo-that showed a venetian-inspired façade - was almost certainly began in the 1470s, when works at Alberti's Sant' Andrea were just started. Moreover, we should mention also private chapels, such as the one of the Striggi family in the church of Santa Maria della Carità. New archival evidences—as the testament of Giovanni Striggi-permit us to date this Gothic architecture to 1486.

\section{The Palaces of Ludovico II Gonzaga and the Medieval Tradition}

\section{The City of Mantua at the Beginning of the Renaissance}

During the second half of the 15th century, and especially after the Diet of 1459 convened by pope Pius II, Ludovico II Gonzaga instigated a real Renovatio Urbis in Mantua (Calzona, 2011, pp. 17-44). The Marquis of 
Mantua undertook a series of interventions in the new antique, or "all'antica" style. In particular, Ludovico's intent was to beautify the piazzas_-following the tenets echoed in the seventh book of the De Re Edificatoria (1452) — to rebuild the city palaces, and to build the Casa del Mercato; in addition, the Marquis substituted the abbey of Sant' Andrea with a new public place of worship which was to be ideally connected to the church of San Sebastiano at the other end of the city. In short, the prince established his personal patronage over the main symbols of political, economic, social, and religious life in Mantua (Bianchi \& Carpeggiani, 2006, p. 31). This campaign of transformation of the city, also pursued by Ludovico's heirs, was further developed by the town's nobility with the construction (or restructuring) of their family residences (Ferlisi, 2002, pp. 297-326).

Moreover, Renaissance painters were already active in Mantua towards the end of the first half of the 15th century, before the arrival of Andrea Mantegna, who had moved to Virgil's home city towards the end of 1459, being already in contact with the Marquis Ludovico II since 1457 (L’Occaso, 2006a, pp. 46-57).

\section{The Palace of Ludovico II Gonzaga at Revere}

In this context, we can expect that the "all'antica" style was almost only used in courtly art and architecture patronized by the Gonzaga. However, most of the new buildings executed under Ludovico II Gonzaga were the result of a felicitous encounter between the medieval tradition and the humanist rediscovery of the ancient Roman home (Rossari \& Scotti, 2005; Scotti, 2001), and, in particular, the Vitruvian sequence consisted of an arched entrance and courtyard with a colonnade which would be developed by Leon Battista Alberti (Fiore, 2006, p. 99).

First of all, we should consider the Marquis' palaces, such as the one at Revere, the "castle on the Po" cited by Filarete (Calzona, 2002, pp. 257-277). The construction of this building must have started at least from 1447 by Antonio Manetti, subsequently, taken over, from 1451 by the Florentine Luca Fancelli under the strict supervision of the Ludovico II Gonzaga (Carpeggiani, 2004, pp. 216-247). At Revere, the suggestions derived from Vitruvius are articulated in the light of the political ambitions of the Gonzaga, his courtly world and its medieval traditions: For example, the courtyard becomes a space for the representation of life at court. Moreover, we should also consider that this courtyard is characterized by both a Renaissance lay-out and late-Gothic Venetian capitals.

We should also mention the main façade (see Figure 1). Here, we find both windows and portals derived from the Tuscan Renaissance and towers, tall chimneys and battlements—even if fake and located under the roof - that evoke medieval castles as symbols of the feudal power of Ludovico II Gonzaga.

\section{Villa Ghirardina}

A similar distributive model characterizes the Villa Ghirardina at Motteggiana, the old villa of Saviola was built around the mid-15th century by Fancelli for Ludovico II (Palvarini Gobio Casali, 1986, pp. 5-34). In this case, the system of entrances becomes a symbolic route in which the main corridor leads directly to a staircase which leads to a hanging courtyard, the "sinum"—or the "heart"—of the house according to Alberti's De Re Aedificatoria (1452). As at Revere, the façades are characterized by Tuscan windows and medieval battlements (see Figure 2). 


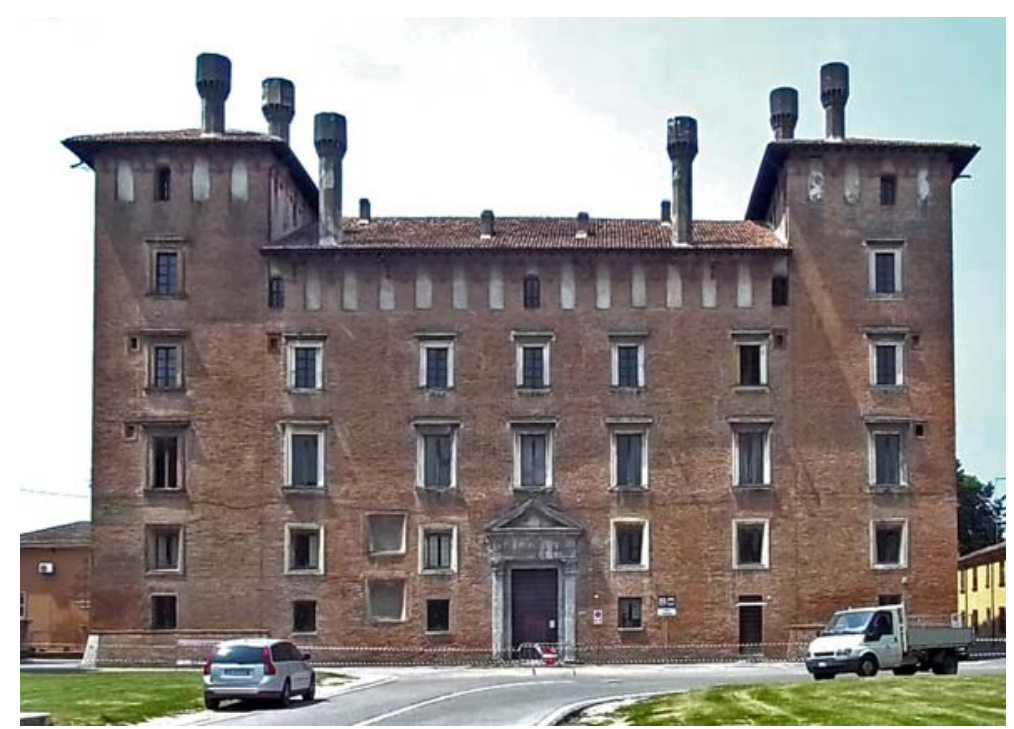

Figure 1. Revere (Mantua), the Palace of Ludovico 2nd Gonzaga.

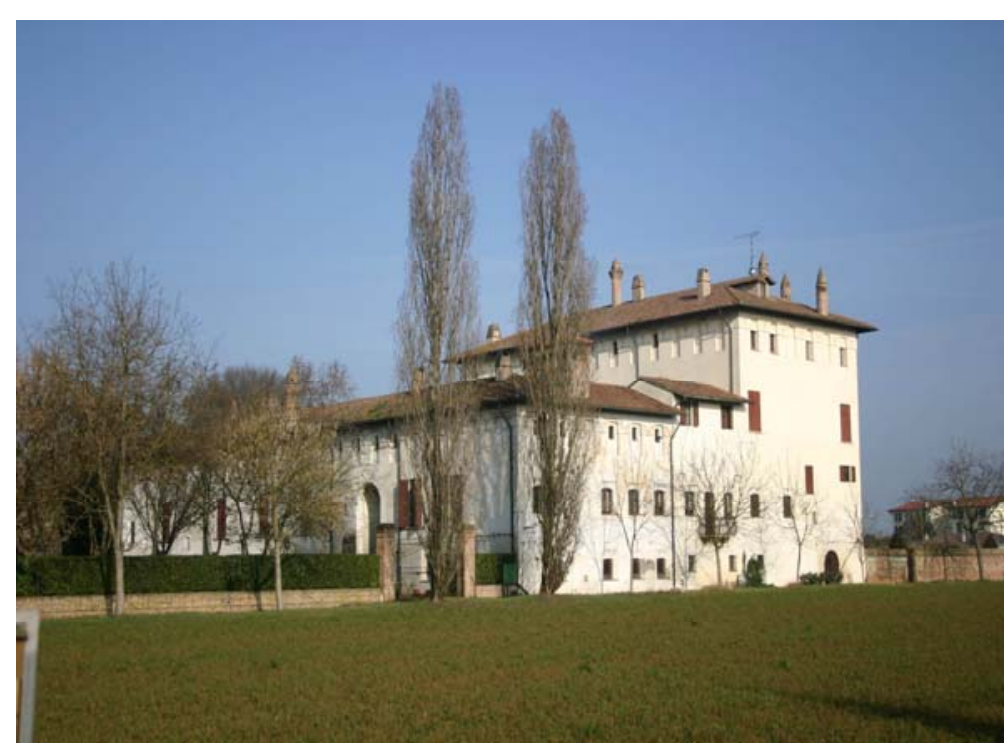

Figure 2. Motteggiana (Mantua), the villa of Ludovico 2nd Gonzaga.

\section{The Castle of San Giorgio and the Domus Nova}

As being already mentioned in early Renaissance, castles were still the most important symbols of the feudal power of a prince; therefore, the refurbishment of the medieval castle of San Giorgio by Marquis Ludovico II Gonzaga (already began perhaps in 1457) is very important (L'Occaso, 2006b, pp. 20-35). The rooms of Ludovico II were subsequently lived in by his son Federico I, who began the construction of a large new residence, the Domus Nova, characterized by towers still inspired by medieval examples, and battlements (now lost, but still visible in a late 16th century drawing) (Togliani, 2003, pp. 95-98). After the death of Federico I (1484), the castle went back to being the ruling centre of power. It is there that Francesco II and his consort Isabella d'Este settled (Togliani, 2003, pp. 98-99). At the beginning of his rule (1519), Federico II also lived in the castle of San Giorgio (L’Occaso, 2011, p. 157). 


\section{The City Palaces}

Before concluding, we should mention the already cited city palaces again. The restoration of the Palazzo della Ragione, with its new loggia, was concluded in 1462 (Ferlisi, 2005, p. 173). Between 1462 and 1564, Luca Fancelli and Giovanni Antonio d'Arezzo worked at the Palazzo del Podestà (as already noted by the Mantuan art historian Ercolano Marani in 1961), we should consider that before the restorations (completed in 1941), the main façade was very similar to that of the palace of Ludovico II at Revere (Marani \& Perina, 1961, pp. 81-82).

\section{Gothic Heritage and Private Houses}

\section{Battlements and Towers in Early Renaissance Palace Façades}

During the second half of the 15th century, some features of the Gonzaga palaces also appeared in private houses built by Mantuan patricians involved in the already mentioned "renovatio urbis" patronized by Marquis Ludovico II. The Mantuan scholar Ercolano Marani (1961) noted that several houses presented battlements-derived from medieval tradition and used in courtly residences-before recent restorations, but important examples still survive ${ }^{1}$ (Marani, 1961, p. 83). First of all, we should consider the early Renaissance house of the merchant Giuliano Lanzini (Piazza Marconi 16, see Figure 3) (Marani \& Perina, 1961, p. 82). Sometimes, these kinds of façades were decorated by frescoes: Human figures are painted between the battlements of the palace of Gian Maria Calvisano (Via Cavriani 4) built in circa 1494 (see Figure 4) (L'Occaso, 2009b, p. 20). A similar decoration—recently attributed to Nicolò da Verona-is in the façade of Palazzo Boldrini (Via Chiassi 42, see Figure 5), probably built in 1470s or 1480s (L'Occaso, 2009b, pp. 19-20; Vischi, 2009, pp. 58-59). Often, these façades combined both Gothic and Renaissance elements: In the courtyard of Palazzo Malatesta, we find Renaissance heraldic devices (see Figure 6) (L’Occaso, 2009b, pp. 19); Between the battlements of the house in Via Massari 11, we find human figures depicted in still late-Gothic style and Renaissance fake-marbles (see Figure 7) directly derived from Mantegna's works, such as the Camera degli Sposi, completed in $1474^{2}$ (Vischi, 2009, pp. 56-57). This fake-marble decoration also appears in a previously unpublished battlement in the courtyard of Palazzo Berla in Via Bertani 31, now incorporated in the top floor (see Figure 8).

Angular towers are also medieval-inspired elements, directly derived from the Gonzaga's residences. Nowadays, the most important example is the tower of Palazzo Arrivabene (Via Fratelli Bandiera 18, see Figure 9), began in 1481 and characterized by a Renaissance entablature (Carlini \& Guidara, 2003; 2004). Moreover, we should mention the tower of the house of the Mantuan humanist Mario Equicola, built in 1522 and destroyed in 1718 (Marani \& Perina, 1961, pp. 92-94).

\footnotetext{
${ }^{1}$ Marani cited houses in Vicolo Poggio, Via Oberdan, Vicolo Santa Maria (No. 8), and Via (No. 5). Marani, E., and Amadei, G. (1977). Antiche dimore mantovane (p. 50). Marani cited a house in Via Chiassi 59. Recent restoration discovered battlements in the facade of the house in Via Cocastelli 10.

2 About wall decorations inspired by Mantegna, see Zuccoli (2006a), pp. 58-69; Zuccoli (2006b), pp. 68-87.
} 


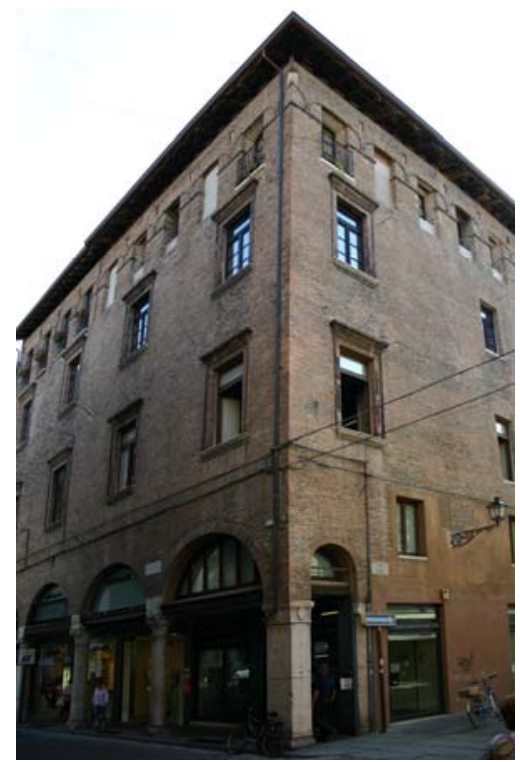

Figure 3. Mantua, Piazza Marconi 16, the house of Giuliano Lanzini.

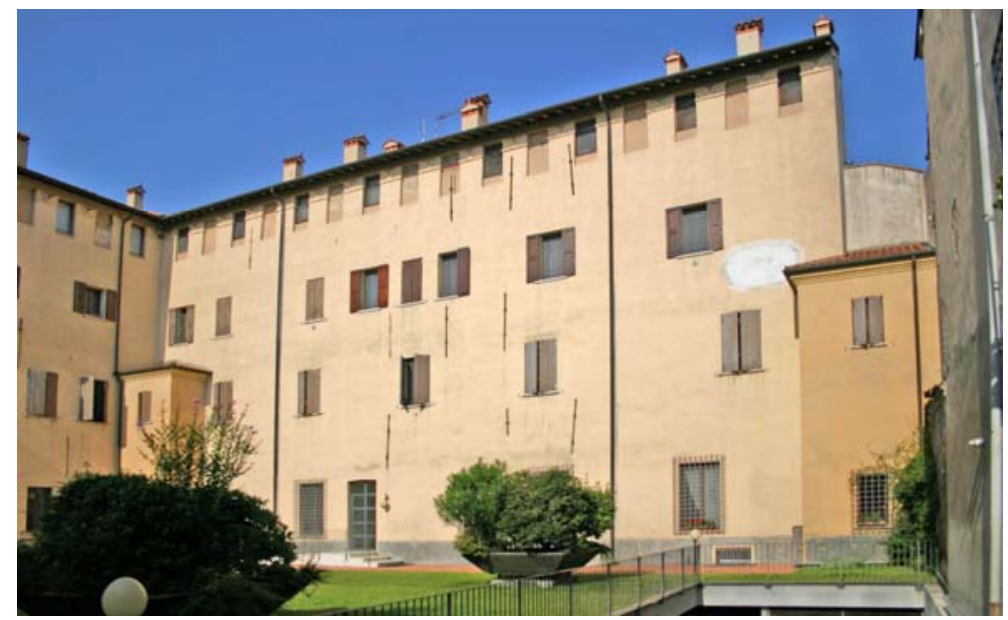

Figure 4. Mantua, Via Cavriani 4, the palace of Gian Maria Calvisano.

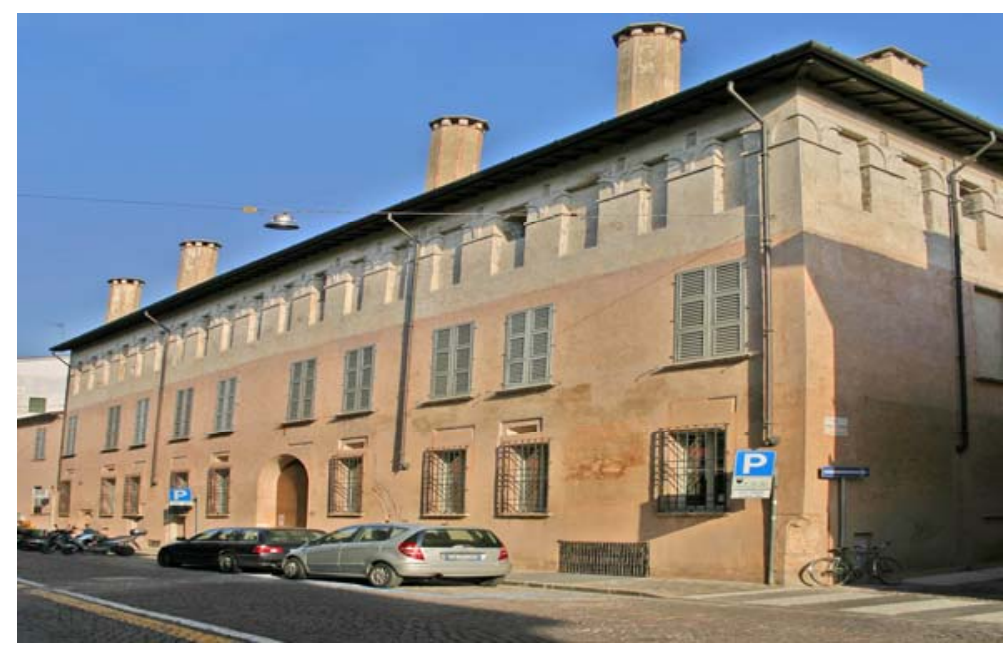

Figure 5. Mantua, Via Chiassi 42, Boldrini palace. 


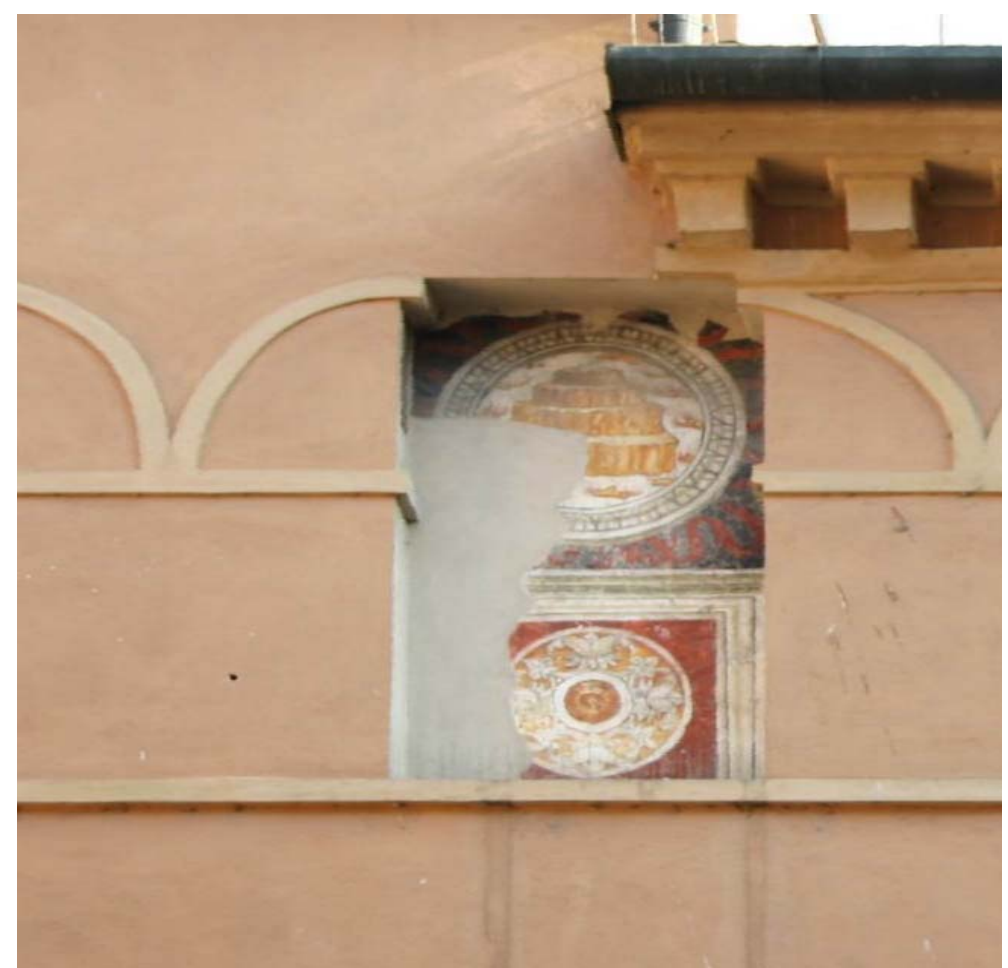

Figure 6. Mantua, Via Mazzini 16, Malatesta palace. A detail of the courtyard.

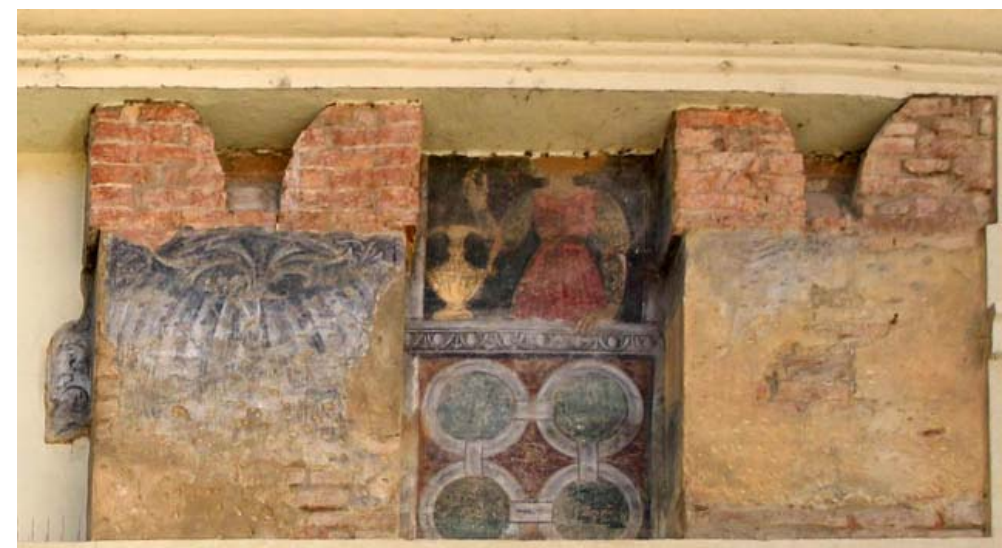

Figure 7. Mantua, Via Massari 11, a detail of the façade.

\section{The House of Giovanni Boniforte da Concorrezzo}

Nowadays, the house of the merchant Giovanni Boniforte da Concorrezzo (Piazza Erbe) is considered the most important example of a late-Gothic façade of a private Mantuan residence (see Figure 10). The archival research by Maria Rosa Palvarini has clarified the building's history: Giovanni bought the house on December 24, 1454 and immediately began restoration; the new façade was already completed in 1455 and this date appeared in the inscription under the loggia (written both in Latin and volgate), in a lost epigraph removed in 1798, the Mantuan chronicler Andrea da Schivenoglia also mentioned the date 1455 (Palvarini Gobio Casali, 1964). 


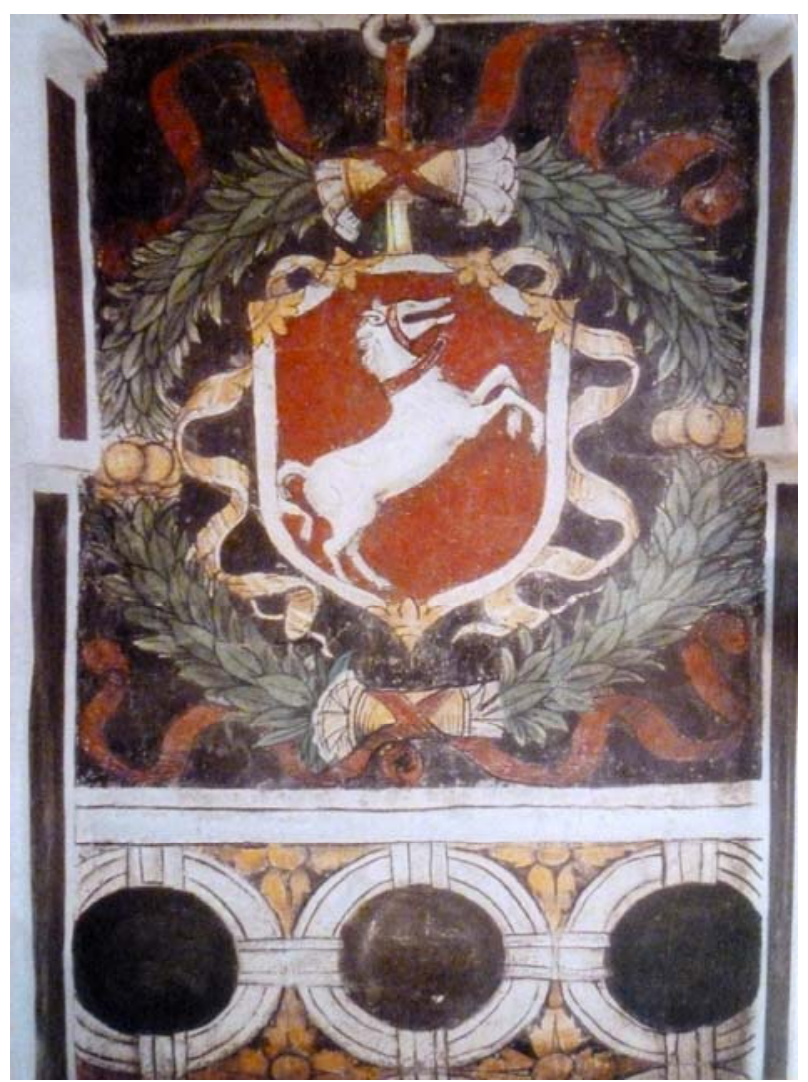

Figure 8. Mantua, Via Bertani 31, Berla palace. A battlement of the courtyard now incorporated in the top floor.

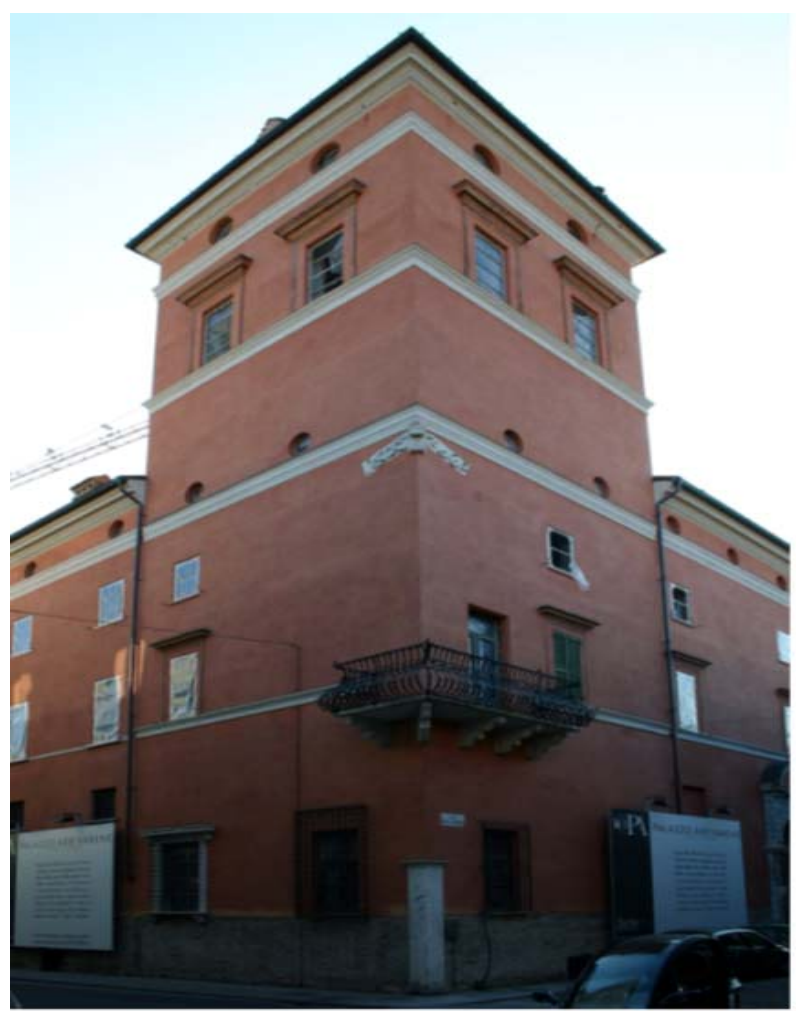

Figure 9. Mantua, Via Fratelli Bandiera 18, Arrivabene Palace. 


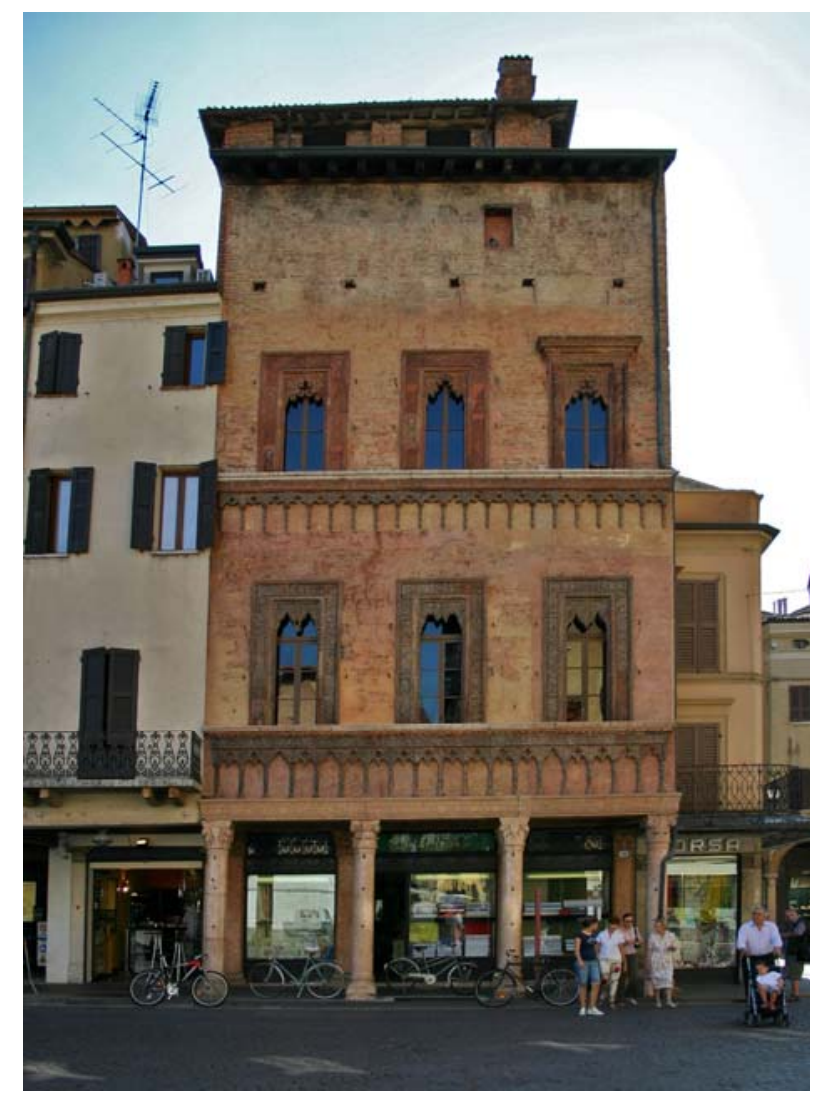

Figure 10. Mantua, Piazza Erbe, the house of Giovanni Boniforte da Concorrezzo.

Now, we know that this façade was originally completely painted and gilded, but today only the terracotta decoration still survives (Vischi, 2009, pp. 38-39). Ercolano Marani identified four cultural areas as sources for this complex architecture: Lombardy for the hanging columns of the horizontal entablatures; Spain and/or southern Italy for the inner decorations of the windows frames; Venice for the loggia and the whole composition; and, last but not least, the early Mantuan Renaissance for the two Corinthian capitals, for the dentils of the architraves and for the flat frontons with dentils that characterize two windows (one on the main façade towards Piazza Erbe, and the other on the side towards Piazza Mantegna) (Marani \& Perina, 1961, pp. 27-28).

However, in the author's personal opinion, the mixture of Gothic and Renaissance elements is more complex: In fact, the ground floor portico is the only the 15th century architraved loggia now known in Mantua; indeed, surviving arcades — both Gothic and early Renaissance — are always characterized by arches. Perhaps, in the loggia of Giovanni Boniforte's house, we can find an echo of the suggestions of Alberti, who theorized that squared pilasters must hold arches while columns must hold architraves (Wittkower, 1964, pp. 38-39). We have to consider that Alberti only arrived in Mantua in 1459, but he had previously been in close contact with the Gonzaga court: Indeed, Alberti dedicated the Latin edition of his De Pictura (1435) to Gianfrancesco Gonzaga, Ludovico II's father ${ }^{3}$. Moreover, we have to consider that some of Alberti's ideas about art and architecture probably arrived in Mantua thanks to the relationships between Ludovico II Gonzaga and Donatello, who had been greatly influenced by Alberti: In 1450, Ludovico II commissioned from Donatello-who had moved to

${ }^{3}$ About Alberti and Mantua, see Calzona (2011), pp. 17-44. 
Padua in 1443/44 — the plastic decoration of a new altar in the Mantuan cathedral, dedicated to Sant'Anselmo (patron saint of Mantua); Donatello executed sketches and models of the statutes, but the altar was never completed (Braghirolli, 1873, pp. 4-10; Marani \& Perina, 1961, pp. 509-510).

\section{Gothic Decoration in Private Renaissance Palaces}

Even though Renaissance painters were active in Mantua from the end of the first half of the 15th century, we also know that Lombard masters anchored to the Gothic heritage were still at work (L'Occaso, 2006a, p. 47). The lost decoration of the palace of the prothonotary Guido Gonzaga-decorated between 1456 and 1459 - seems to testify to this mixture of Gothic style and new Renaissance culture (L'Occaso, 2006a, p. 51-52). This palace was characterized by a "camera Socratis", almost certainly painted with Socrates and other "Uomini dotti" (famous people from the classical world); probably, this decoration was the one-now lost—discovered in 1890 in the palace which now hosts the Accademia Nazionale Virgiliana and the Conservatorio Lucio Campiani: Greeks philosophers (such as Democritus, Plato, Diogenes, Anaxagoras, and Aeschylus) protagonists of the Bible (Abraham, Joseph, Assuerus, Ester) figures from Greek mythology (Prometheus) or from the ancient Middle-East (as Zoroaster and Semiramis) were painted in three orders of Gothic arches. As noted by Stefano L'Occaso (2006a), this decoration was probably under a loggia—according to the Renaissance treaty of Filarete (who was in Mantua in 1459-and the paintings could have been inspired by the Speculum historiale by Vincenzo of Beauvais, quoted in 1407 in the inventory of the Gonzaga library, which also served for Masolino's Uomini illustri painted in 1432 in the Roman palace of Cardinal Giordano Orsini.

Recently, the author has discovered an important wall decoration in a private house located in Piazza Stretta 2 (see Figure 11) (Girondi, 2012a, p. 14). The frieze shows vegetable ornaments on a white background - following the Gothic Mantuan tradition (Suitner, 1989, pp. 15-16)—which surround coats of arms depicted in fake-marbled Renaissance tondi and not in medieval poly-lobed frames; also the 2-again fake-marbled - entablatures (at the bottom and at the top of the freeze) are very important, because they show dentils inspired by the new "all' antica” style. The frescoes were probably executed in the 1440s or 1450s, and certainly after 1433, when Gianfrancesco Gonzaga received the title of Marquis of Mantua and a new coat of arms with imperial eagles. Moreover, we should note the Mantuan journey of Filippo Brunelleschi in the 1430s and 1440s (L'Occaso, 2005, pp. 23, 84-86).

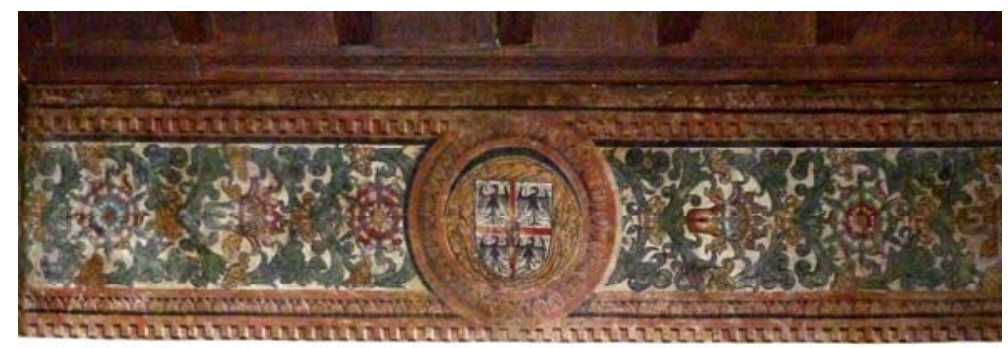

Figure 11. Mantua, Piazza Stretta 2, A frieze.

Other frescoes which combine Renaissance and Gothic elements are in the Uberti Palace, located in Piazza Seminario 1 and perhaps executed in the 1460s or $1470 \mathrm{~s}^{4}$. Here, we find a medieval white background again,

\footnotetext{
${ }^{4}$ The author wants to thank Stefano L'Occaso for the suggestion about the date of these frescoes.
} 
filled by Gothic dragons and early Lombard Renaissance putti that surround garlands "all'antica" with coats of arms and busts of Roman emperors.

In addition, the author wants to present wall decorations that he has recently found in two private houses (Via Conciliazione 90, see Figure 12, and Via XX Settembre 17, see figure 13) (Girondi, 2012a, pp. 14-15). Here we find putti-inspired by Lombard art again — who stand between coats of arms and still Gothic vegetable volutes. These frescoes are very important, because they were executed using the same preparatory cartoons, and this detail testifies the diffusion of this technique, also used in Mantua for the fresco depicting the Three Consuls of the University of the Merchants (L’Occaso, 2006a, p. 48), and for the Pisanello Arthurian cycle (Castrichini, 1996, p. 76). Thanks to the 19th century Mantuan art scholar Carlo d'Arco, we know that in 1474 Bartolomeo Cavazzi was “civis notarius Mantuae de c[ontrat]a equi” (the ancient name of Via XX Settembre) ${ }^{5}$. Perhaps, Bartolomeo was the patron of these frescoes: The Cavazzi coat of arms is painted into a garland, and in another one, we can find a cross surrounded by the fragments of two letters, possibly the $\mathrm{C}$ and $\mathrm{B}$ from the name of the gentleman. These frescoes also feature a series of small arches-that characterized several 15th century late-gothic Mantuan façades_-while the decoration in Via Conciliazione shows Renaissance entablatures with dentils, such as the one in the courtyard of the Valentini Palace in Corso Vittorio Emanele II 52 (see Figure 14) (Suitner \& Nicolini, 1987, p. 71).
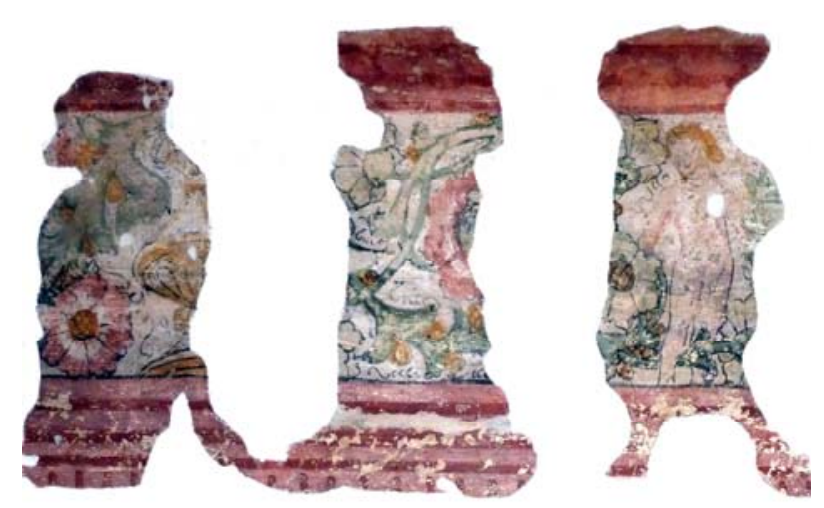

Figure 12. Mantua, Via Conciliazione 90, A frieze.

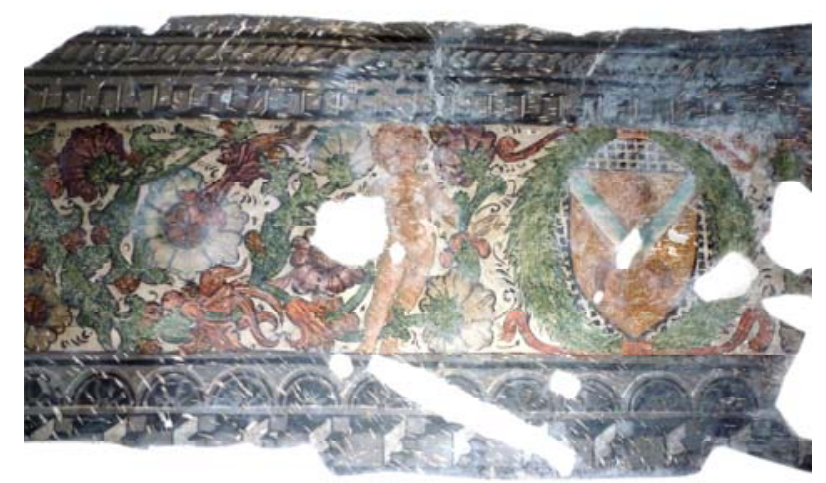

Figure 13. Mantua, Via XX Settembre 17, the house of Bartolomeo Cavazzi, A frieze.

\footnotetext{
${ }^{5}$ Archivio di Stato di Mantova, Documenti Patrii D’Arco, Famiglie Mantovane, II (State Archive of Mantua, Documents of the homeland by Carlo d'Arco, Mantuan families, II), c. 190.
} 


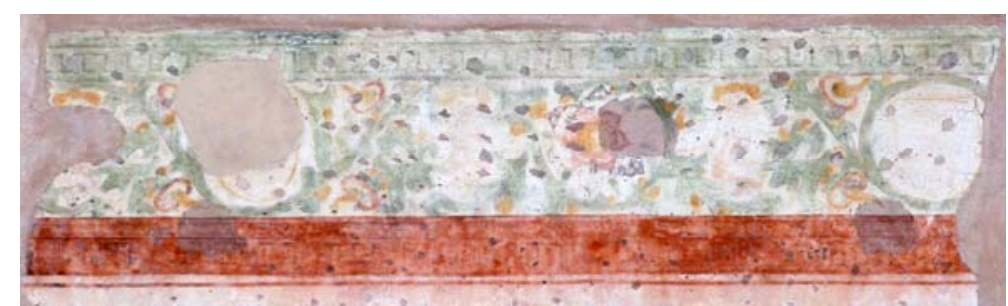

Figure 14. Mantua, Corso Vittorio Emanuele II 52, A detail of the courtyard.

During the second half of the 15th century, Gothic decorations often continued to characterize wooden ceilings - especially on the tablets between the beams - also when Renaissance frescoes were painted on the walls. The use of coats of arms surrounded by vegetable volutes comes from a medieval tradition: For example, we should consider the loggia of the Palazzo del Capitano, executed in the 14th century (Rodella, 2003, p. 28). Coats of arms characterize the wooden ceiling of several 15th century Mantuan palaces: We have to mention a large room in the palace of the Cavriani family, bought by Luigi, Giovanni e Benedetto Cavriani in 1446 (Tamalio, 2012, p. 34). This ceiling also shows other kinds of decorations, such as anthropomorphic and zoomorphic monsters, according to a specific typology which was quite common particularly in Viadana (near Mantua) (Bazzotti, 1993, pp. 279-280) and Cremona (Aglio, 2005, pp. 289-297). Monsters also characterize other wooden ceilings: We should mention a room in the previously mentioned house of Bartolomeo Cavazzi (see Figure 15), and others in the houses of Via Fratelli Bandiera 10 and Via Massari 11 (see Figure 16); these examples are very interesting, because some decorations were executed using the same preparatory cartoons (Girondi, 2012a, pp. 45-46).

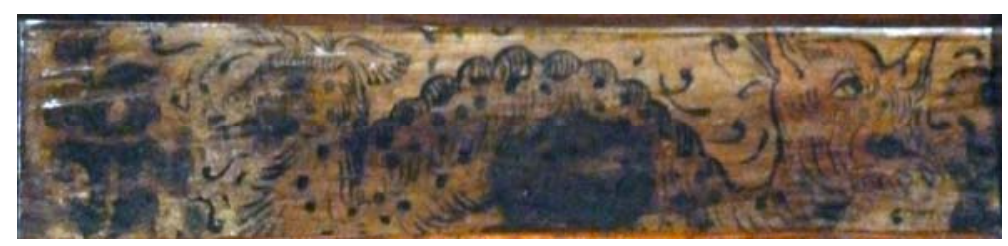

Figure 15. Mantua, Via XX Settembre 17, the house of Bartolomeo Cavazzi, A detail of a wooden ceiling.

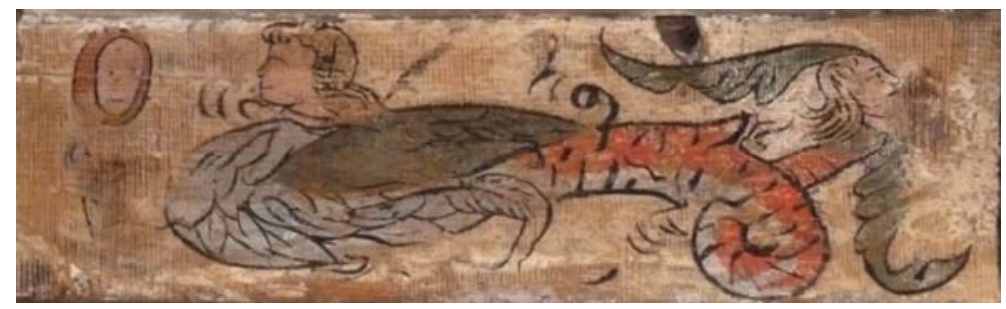

Figure 16. Mantua, Via Massari 11, A detail of a wooden ceiling.

\section{Gothic Churches and Chapels in Renaissance Mantua}

\section{San Cristoforo}

In Renaissance Mantua, Gothic heritage also characterized religious architecture. First of all, we should consider the church of San Cristoforo: In 1613, the Mantuan chronicler Ippolito Donesmondi wrote that "verso" (about) 1479 the Celestine friars built the new church, thanks to the Andreasi and Monza families (Donesmondi, 1613, p. 386; 1616, p. 59). A manuscript written in 1675—and recently discovered by Stefano L'Occaso—confirms 
the date 1479 and quotes a now lost tombstone of the Monza family (L’Occaso, 2009c, pp. 59-71).

The church-restored in the interior during the 18th century-still shows the original exteriors (see Figure 17): An early Renaissance portal is the only element executed "all'antica"; In fact, the salient façade — with traces of a large rose window—and the corbelled trefoil frieze in the eaves cornice were directly derived from late-Gothic Venetian architecture.

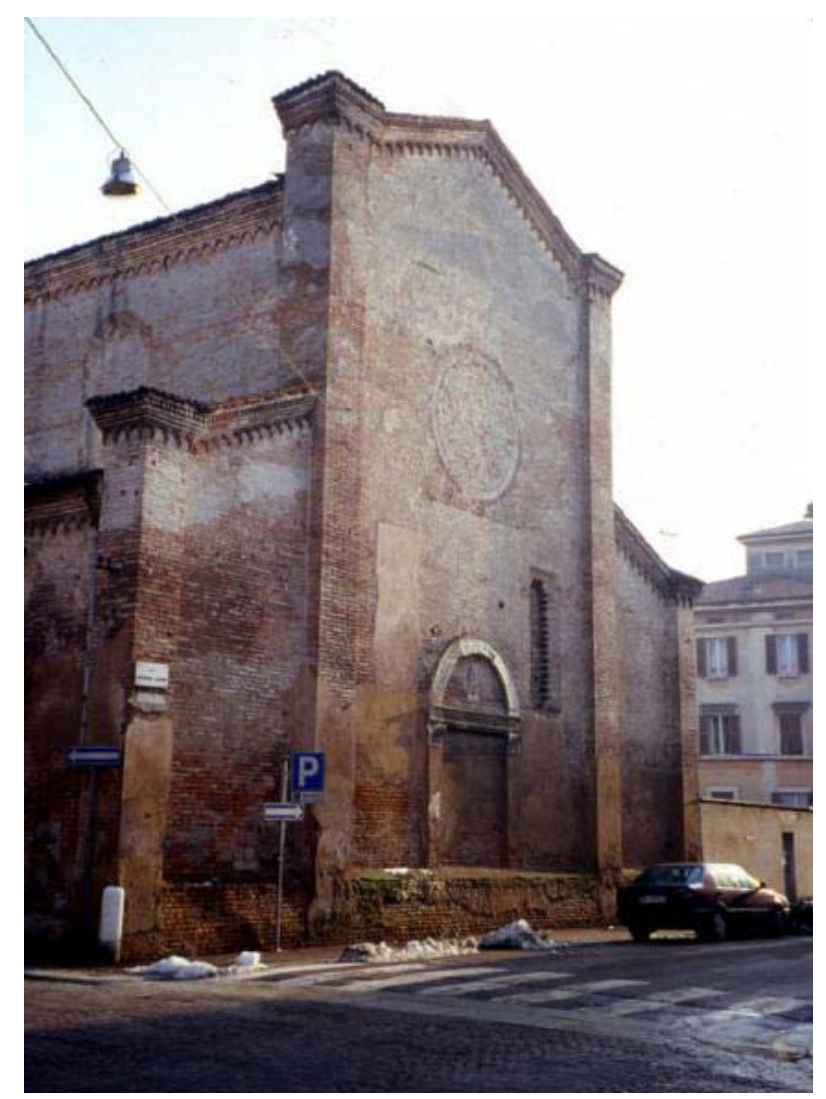

Figure 17. Mantua, San Cristoforo.

\section{The Striggi Chapel in Santa Maria Della Carità}

The author has recently studied the history of the Striggi Chapel in the church of Santa Maria della Carità (Girondi, 2010; 2012b, pp. 71-99). The chapel was built thanks to the testament of Giovanni Striggi, written on February 11, $1486^{6}$. The testament of Giovanni's son, Giacomo, drawn up on August 27, 1500, testified that the chapel was already "constracta, et fabricate" was created only on February 4, $1523^{8}$. Perhaps the Renaissance frescoes were executed on this occasion; indeed, the paintings show the style of the late Mantuan classicism that characterized the last few years before the arrival of Giulio Romano (1524). The architecture of this chapel was very interesting, in particular because

\footnotetext{
${ }^{6}$ Archivio di Stato di Mantova, Archivio Notarile (State Archive of Mantua, Notary Archive), Antonio Cornice, b. 22bis, Fubrurary 11, 1486.

7 Ibid, Francesco Pagani, b. 425, August 27, 1500.

${ }^{8}$ Giovanni, Carminiati. (1523, February 4). Alberto e Giovanni Battista, Dotatio et errectio capelle et benefitis sanctis Ioannis Bapte, et Alberti (foundation of the chapel and benefice of Saint John the Baptist, and Saint Albert). Archivio Storico della Diocesi di Mantova, Benefici (Historical Archivo of the Diocese of Mantua, benefice), b. 31/2, fasc..
} 
of its cross vault still characterized by Gothic ogival arches (see Figure 18). On the other hand, the Renaissance genesis of the chapel is testified by the Man of sorrow attributed to Elia della Marra (documented between 1464 and 1495) and probably executed in 1486 or later (L'Occaso, 2009a). This terracotta is located over the main entrance of the chapel and an inventory drawn up in 1737 testifies that the façade was also characterized by an oculus, recently, rediscovered during the restorations ${ }^{9}$.

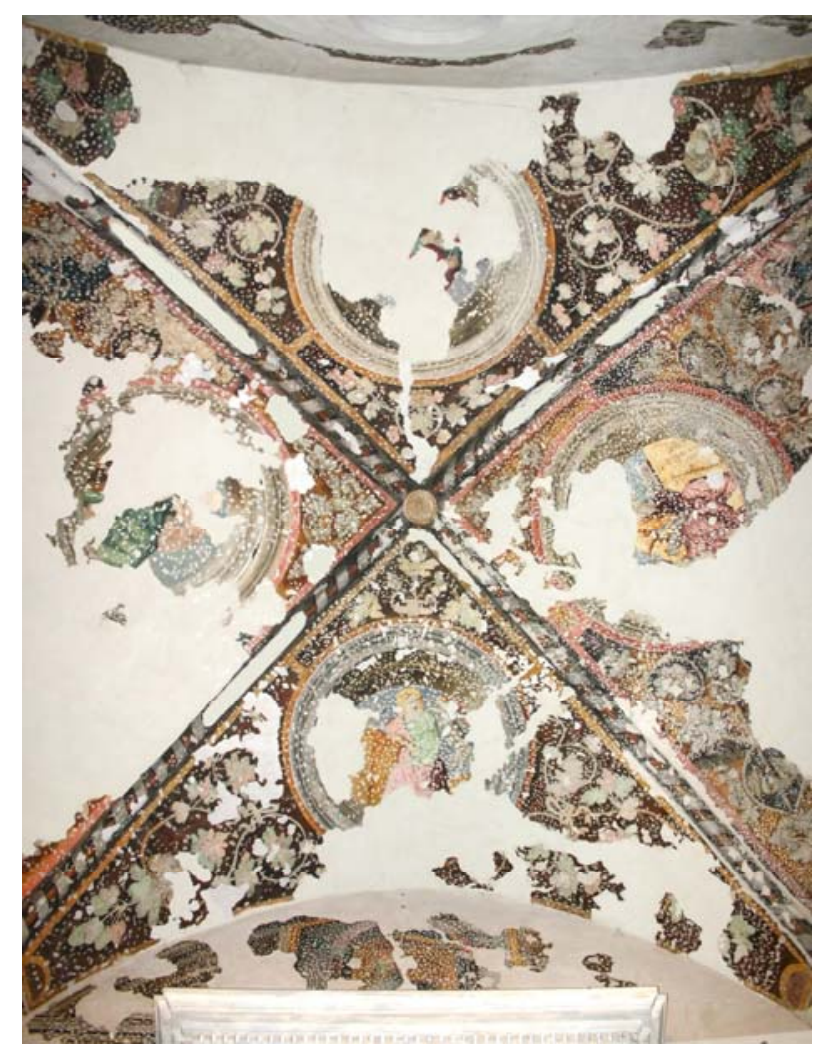

Figure 18. Mantua, Santa Maria della Carità, the Striggi Chapel.

\section{The Church of Madonna Della Vittoria}

The building history of the church of Madonna della Vittoria (see Figure 19) has been clarified by Ugo Bazzotti (Bazzotti, 2006, pp. 200-219). On July 6, 1496, the votive church-wished by marquis Francesco II Gonzaga, victorious at Fornovo, in the place of the demolished house of the persecuted Jew, Daniele Norsa - was officially inaugurated with a large procession that accompanied the altarpiece executed by Andrea Mantegna. Giorgio Vasari wrote that the church was also executed “con ordine e disegno di Andrea”(following a design by Mantegna), but almost certainly Vasari referred to the interior architectural ornaments only, recently rediscovered and painted in the style of Mantegna. Indeed, the exterior façades still show late-Gothic elements, probably designed — as suggested by Bazzotti—by Bernardino Ghisolfo, who was the Gonzaga court architect between 1490 and 1517. Originally, the church did not present the portal on Via Fernelli (executed at the end of the 19th century), while the main portal on the main façade was larger and characterized by an ogival

\footnotetext{
${ }^{9}$ Archivio Storico della Diocesi di Mantova, Benefici, fasc. Inventari, (Historical Archivo of the Diocese of Mantua, benefice, fascicle Inventories), b. 31/1, inventory written in 1738 by don Francesco Solferini.
} 
arch, destroyed after the transformation of the church into a military storehouse in 1877, when the interior space was divided into two floors. However, some ancient details still survive: In particular, we should mention the general layout, derived from several Mantuan Gothic churches built at the end of the 14th or at the beginning of the 15th century, such as the sanctuary of the Madonna delle Grazie at Curtatone, the church in the village of Angeli, and the urban church of Santa Paola; Moreover, we must look at the original circular window and, last but not least, at the trefoil small arches that characterize the eaves' cornice and which is completely identical to the one on the late-Gothic bell tower in the church of Ognissanti (Bertelli, 2011, p. 56).

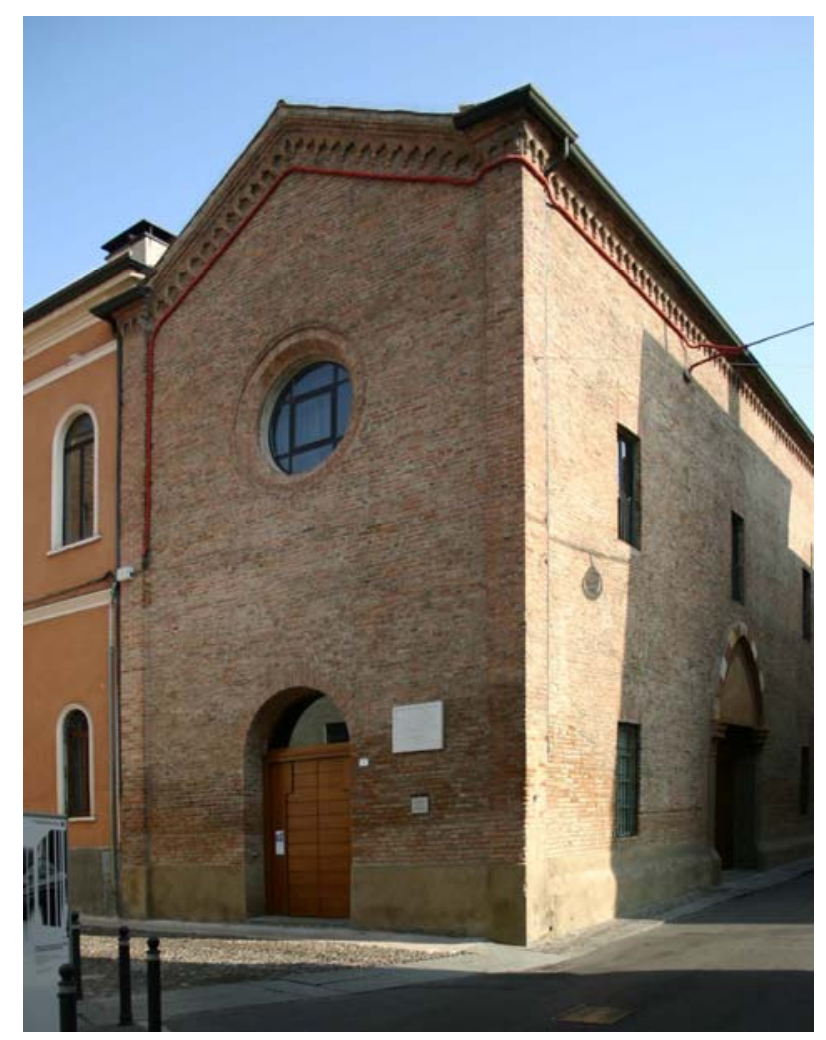

Figure 19. Mantua, Madonna della Vittoria.

\section{Conclusions}

Now we can try to make some conclusions. First of all, the list of quoted buildings, both religious and profane, seems demonstrate that during the late 15th century, the Gothic heritage maintained a key-role in the artistic life in Mantua, even if the medieval tradition was often mixed with the new "all'antica” style. For example, we can find late-Gothic architectures, characterized by some Renaissance details, such as the church of San Cristoforo (with a Renaissance main door), the house of Giovanni Boniforte da Concorrezzo (with Renaissance capitals), and the Striggi Chapel (decorated by the sculptures by Elia della Marra). On the other hand, we have Renaissance buildings with still Gothic details: For example, we should consider the palaces by (or inspired by) Luca Fancelli, characterized by battlements and towers derived from medieval castles. 


\section{References}

Aglio, R. (2005). Bestiari dipinti: Tavolette da soffitto e modelli iconografici (Painted bestiary: ceiling tablets and iconographical models). In M. Rossi (Ed.), Lombardia gotica e tardogotica: Arte e architettura (Gothic and late-Gothic Lombardy: Art and architecture) (pp. 289-297). Milan: Skira.

Bazzotti, U. (1993). Mantova (Mantua). In V. Terraroli (Ed.), La pittura in Lombardia: Il Quattrocento (Painting in Lombardy: The 15th century) (pp. 243-286). Milan: Electa.

Bazzotti, U. (2006). La chiesa di Santa Maria della Vittoria e la pala di Andrea Mantegna (The church of Saint Mary of the Vicory and the altarpiece of Andrea Mantegna). In R. Signorini (Ed.), A casa di Andrea Mantegna: Cultura artistica a Mantova nel Quattrocento (At home of Andrea Mantegna: Artistic culture in Mantua during the Quattrocento) (pp. 200-219). Cinisello Balsamo, Milan: Silvana Editoriale.

Bertelli, P. (2011). L'antica parrocchiale di Ognissanti: Storia e arte (The ancient parrish church of All Saints: History and art). In P. Bertelli, \& N. Sodano (Eds.), Chiesa di Ognissanti (Church of All Saints) (pp. 11-83). Mantua: Sometti.

Bianchi, M., \& Carpeggiani, P. (2006). Ludovico Gonzaga, la città, l’architettura: Uno scenario per Andrea Mantenga (Ludovico Gonzaga, city and architecture: A background for Andrea Mantegna). In R. Signorini (Ed.), A casa di Andrea Mantegna: Cultura artistica a Mantova nel Quattrocento (At home of Andrea Mantegna: Artistic culture in Mantua during the Quattrocento) (pp. 20-45). Cinisello Balsamo, Milan: Silvana Editoriale.

Braghirolli, W. (1873). Donatello a Mantova: Con documenti inediti (Donatello in Mantua: With unpublished documents). Giornale d'erudizione artistica (Journal of Artistic Erudition), 2(11), 4-10.

Calzona, A. (2002). Ludovico II Gonzaga principe “intendentissimo nello edificare” (Ludovico II Gonzaga prince "really expert in building”). In A. Calzona et al. (Eds.), Il Principe architetto (The prince architect) (pp. 257-277). Florence: Olschki.

Calzona, A. (2011). Illis civium nostrorum petitionibus libenter annuimus quas ipsorum comodo urbis non minore decore ac ornamento futuras esse videremus: Ludovico II Gonzaga e le strategie urbane a Mantova al tempo dell'Alberti (To the requests of those our citizens, we gladly respond that we will provide soon for their benefit and not less for the decorum and ornament of the city: Ludovico II Gonzaga and the urban strategies in Mantua at the time of Alberti). In P. Boucheron, \& M. Folin (Eds.), I grandi cantieri del rinnovamento urbano: Esperienze italiane ed europee a confronto (secoli XIV-XVI) (Great constructions of urban renewal: A comparison between Italian and European experiences) (pp. 17-44). Rome: Ecole Française de Rome.

Carlini, D., \& Guidara, M. (2003-2004). La Torre di palazzo Arrivabene a Mantova: dall'analisi della fabbrica alle ipotesi di conservazione (The tower of the Arrivabene Palace in Mantua: From construction analysis to preservation hypothesis) (Degree dissertation). Politecnico di Milano: Facoltà di Architettura e Società.

Carpeggiani, P. (2004). Luca Fancelli e la scultura decorativa nel contado gonzaghesco (Luca Fancelli and the decorative sculpture in the Gonzaga countryside). In F. Monicelli (Ed.), Scultura in villa nella Terraferma Veneta, nelle Terre dei Gonzaga e nella Marca Anconetana (Sculpture in villa in the Venetian mainland, in the countryside of the Gonzaga and in the March of Ancona) (pp. 216-247). San Giovanni Lupatoto, Verona: Arsenale.

Castrichini, M. (1996). Pisanello: Restauri ed interpretazioni (Pisanello: Restorations and interpretations) (p. 76). Todi, Perugia: Ediart.

Donesmondi, I. (1613). Historia Ecclesiastica di Mantova I (Mantuan history of the Church I) (p. 386). Mantua: Osanna.

Donesmondi, I. (1616). Historia Ecclesiastica di Mantova II (Mantuan history of the Church II) (p. 59). Mantua: Osanna.

Ferlisi, G. (2002). I palazzi dei cortigiani e le scelte architettoniche e urbanistiche di Ludovico Gonzaga (Courtiers palaces and architectural and urban choices of Ludovico Gonzaga). In A. Calzona et al. (Eds.), Il principe architetto (The prince architect) (pp. 297-326). Florence: Olschki.

Ferlisi, G. (2005). Entro mura d'acqua e di pietra: Dinamiche insediative e progetti dinastici dai Canossa ai Gonzaga (Within walls of water and stone: Settlement dynamics and dinastic projects from the Canossa to the Gonzaga). In A. M. Romani (Ed.), Storia di Mantova (History of Mantua) (pp. 177-191). Mantua: Tre Lune.

Fiore, F. P. (2006). Leon Battista Alberti, palazzi e città (Leon Battista Alberti, palaces and cities). In M. Bulgarelli et al. (Eds.), Leon Battista Alberti e l'architettura (Leon Battista Alberti and architecture) (p. 99). Cinisello Balsamo, Milan: Silvana.

Girondi, G. (2010). La chiesa di Santa Maria della Carità in Mantova (The church of Saint Mary of the charity in Mantua). Mantua: Sometti. 
Girondi, G. (2012a). Residenze patrizie a mantova: Decorazioni del rinascimento e del manierismo (Patrician residences in Mantua: Renaissance and Mannerist decorations). Rome: “L’ERMA” di Bretschneider.

Girondi, G. (2012b). Santa Maria della Carità (Saint Mary of the Charity). In R. Golinelli Berto (Ed.), Quaderni di San Lorenzo, X (Notebooks of San Lorenzo) (pp. 71-99). Mantua: Tipografia Commerciale.

L'Occaso, S. (2005). Fonti archivistiche per le arti a Mantova tra Medioevo e Rinascimento: 1382-1459 (Archival sources for the arts in Mantua between the Middle Ages and the Renaissance). Mantua: Arcari.

L’Occaso, S. (2006a). Artisti a Mantova prima dell'arrivo di Andrea Mantegna (Artists in Mantua before the arrival of Andrea Mantegna). In R. Signorini (Ed.), A casa di Andrea Mantegna: Cultura artistica a Mantova nel Quattrocento (At home of Andrea Mantegna: Artistic culture in Mantua during the Quattrocento) (pp. 46-57). Cinisello Balsamo, Milan: Silvana Editoriale.

L’Occaso, S. (2006b). “questi logiamenti de castello siano forniti ed adaptati...”: Trasformazioni e interventi in castello all'epoca del Mantegna ("These apartments in the castle have to be furnished and adapted...": Transormations and works in the castle at the time of Mantegna). In F. Trevisani (Ed.), Andrea Mantegna e i Gonzaga (Andrea Mantegna and the Gonzaga) (pp. 20-35). Milan: Electa.

L’Occaso, S. (2009a). Elia della Marra: Un plasticatore mantovano del secondo Quattrocento (Elia della Marra: A mantuan sculpturer in the late 15th century). Vitelliana, VI, 55.

L’Occaso, S. (2009b). Le facciate dipinte nella Mantova di Andrea Mantegna (e nel Cinquecento) (Painted façades in the Mantua of Andrea Mantegna, and in the 16th century). In G. Bazzotti, S. L’Occaso, \& F. Vischi (Eds.), Facciate dipinte nella Mantova di Andrea Mantegna (Painted façades in the Mantua of Andrea Mantegna) (pp. 11-35). Milan: Skira.

L’Occaso, S. (2009c). San Cristoforo. In R. Golinelli Berto (Ed.), Quaderni di San Lorenzo, VII (Notebooks of San Lorenzo) (pp. 59-77). Mantua, Tipografia Commerciale Cooperativa.

L’Occaso, S. (2011). Museo di Palazzo Ducale: Catalogo generale delle collezioni inventariate. Dipinti fino al XIX secolo (The Museum of the Ducal Palace: General catalogue of the inventoried collections. Paintings up to the 19th century). Mantua: Publi Paolini.

Marani, E., \& Amadei, G. (1977). Antiche dimore mantovane (Ancient mantuan mansions). Mantua: Citem.

Marani, E., \& Perina, C. (1961). Mantova: Le arti, II (Mantua: The arts, II). Verona: Istituto Carlo d'Arco per la storia di Mantova.

Palvarini Gobio Casali, M. R. (1964). La casa di Giovanni Boniforte da Concorrezzo (The house of Giovanni Boniforte da Concorrezzo). Mantova: L’artistica.

Palvarini Gobio Casali, M. R. (1986). La Ghirardina di Motteggiana ovvero la “Casa di Saviola” del Marchese Ludovico II Gonzaga (The villa Ghirardina at Motteggiana, or the "house of Saviola” of Marquis Ludovico II Gonzaga). Civiltà mantovana, 11, 5-34.

Rodella, G. (2003). Le strutture architettoniche (Architectural structures). In G. Algeri (Ed.), Il Palazzo Ducale di Mantova, Mantova (The Ducal Palace of Mantua) (pp. 17-52). Mantua: Sometti.

Rossari, A., \& Scotti, A. (2005). Aspetti dell'abitare e del costruire a Roma e in Lombardia tra XV e XIX secolo (Aspects of housing and building in Rome and Lombardy between 14th and 19th century). Milan: Unicopli.

Scotti, A. (Ed.). (2001). Aspetti dell'abitare in Italia tra XV e XVI secolo: Distribuzione, funzioni, impianti (Aspects of housing in Italy between 14th and 16th century: Lay-out, functions, devices). Milan: Unicopli.

Suitner, G. (1989). L'età di Gianfrancesco Gonzaga e il Pisanello: La decorazione nel passaggio dal Tardogotico al Rinascimento (The time of Gianfrancesco Gonzaga and Pisanello: Decoration in the transition from late-Gothic to the Renaissance). In M. Gregori (Ed.), Pittura a Mantova dal Romanico al Settecento (Painting in Mantua from the Romanesque to the 18th century) (pp. 9-17). Cinisello Balsamo, Milan: CARIPLO.

Suitner, G., \& Nicolini, D. (1987). Mantova: L'architettura della città (Mantua: The architecture of the city). Milan: Marcosy Marcos.

Tamalio, R. (2012). La nobile famiglia Cavriani di Mantova, signori di Sacchetta, marchesi di Colcavagno. Profilo storico (The noble family of the Cavriani of Mantua, lords of Sacchetta, Marquises of Colcavagno. An historical profile). In D. Ferrari (Ed.), I Cavriani: Una famiglia mantovana (The Cavriani: A mantuan family) (p. 34). Mantua: Sometti.

Togliani, C. (2003). L'architettura da Fancelli a Giulio Romano (The architecture from Fancelli to Giulio Romano). In G. Algeri (Ed.), Il Palazzo Ducale di Mantova (The Ducal Palace of Mantua) (pp. 95-98). Mantua: Sometti.

Vischi, F. (2009). Facciate dipinte nella Mantova di Andrea Mantegna (Painted façades in the Mantua of Andrea Mantegna) (pp. 36-67). G. Bazzotti, S. L’Occaso, \& F. Vischi, (Eds.). Milan: Skira. 
Wittkower, R. (1964). Principi architettonici nell'età dell'Umanesimo (Architectural Principles in the Age of Humanism) (Italian ed.) (pp. 38-39). Turin: Einaudi.

Zuccoli, N. (2006a). Forme della decorazione architettonica a Mantova nell'età di Andrea Mantegna (Aspects of architectural decoration in Mantua at the time of Andrea Mantegna). In R. Signorini (Ed.), A casa di Andrea Mantegna: Cultura artistica a Mantova nel Quattrocento (At home of Andrea Mantegna: Artistic culture in Mantua during the Quattrocento) (pp. 58-69). Cinisello Balsamo, Milan: Silvana Editoriale.

Zuccoli, N. (2006b). Decorazione architettonica e aura mantegnesca (Architectural decoration and mantegnesque aura). Nel segno di Andrea Mantegna: arte e cultura a Mantova in età rinascimentale (In the sign of Andrea Mantegna: Art and culture in Mantua during the Renaissance era) (pp. 68-87). Modena: Il Bulino. 